\title{
Development of Word-of-Mouth Elasticity Measures for Tourism Product Categories
}

\author{
Yimiao Chen ${ }^{1}$, Fangyi Liu ${ }^{2 *}$, Li-Ming $\mathrm{Ho}^{2}$, Tom M. Y. Lin ${ }^{1}$ \\ ${ }^{1}$ Department of Business Administration, National Taiwan University of Science and Technology, \\ Taipei, Chinese Taipei \\ ${ }^{2}$ Department of Marine Leisure Management, National Kaohsiung Marine University, \\ Kaohsiung, Chinese Taipei

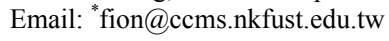

Received June 21 $1^{\text {st }}, 2012$; revised July $24^{\text {th }}, 2012$; accepted August $28^{\text {th }}, 2012$

\begin{abstract}
This study examines the influence of word of mouth (WOM) on eight tourism products by applying economic elasticity theory to understand the relationship between behavioral outcomes and target elements to these behavioral outcomes (customer consumption). The elasticity model of economics was developed to conceptualize WOM elasticity $\left(\mathrm{E}_{\mathrm{WOM}_{\mathrm{x}}}\right)$ and measure WOM effects on various products. The results of WOM elasticity values show a significant difference between physical and service product categories. In addition, all effective respondents in this research are highly sensitive to WOM relating to specific products. This shows that WOM is not only a key variable of tourism products but also validates that WOM communications are meaningful for tourism customers. The authors contributes to tourism service and WOM marketing effects compared by validating empirical research in eight different product categories and providing empirical support with prior services marketing literature. Theoretical and practical implications and future research issues are discussed.
\end{abstract}

Keywords: Tourism Product Categories; Word-of-Mouth; Elasticity Logic; Purchase Drivers

\section{Introduction}

Word-of-mouth (WOM) is an important issue in marketing. Numerous studies have demonstrated that WOM is an effective marketing tool, for example, Lan et al. (2012) shows people like to talk and spread information in their familiar group, whether products are sold at street vendors, night markets, general shops or internet auction sites, most of customers receive in-formation from their very close acquaintances. Villanueva et al. (2008) concluded that the lifetime value of customers acquired through WOM is twice as great as that acquired through traditional marketing tools and Trusov et al. (2009) pointed out that WOM in website member acquisition is 30 times higher than media appearances. Furthermore, we understand WOM can help purchase decision making (Harrison-Walker, 2001; Crane \& Lynch, 1988), especially in innovative products (Dodson \& Muller, 1978; Arndt, 1967); durable goods (Mahajan et al., 1990; Kiel \& Layton, 1981), and professional services (File et al., 1994; Murray, 1991); thus, the WOM effects are vary across products, markets (Ennew et al., 2000), and even brands. The potential impact of WOM and its value to an organization is thus considerable, although the dominant explanation focuses on the role of WOM as a risk-reliever or as a risk reduction strategy (Fang et al, 2011; Forsythe, 2003; Derbaix, 1983), the comparison for WOM influence on different products may be more difficult to identify. Therefore, this study will directly combines economic elasticity theory and WOM research to explore a comprehensive principle for not only quantifying WOM effects but also mirroring the primary cause in various WOM phenomena, with a one-size-fits-all standard of WOM

\footnotetext{
*Corresponding author.
}

quantification in market research can better use this effective marketing tool.

Price elasticity theory originates from economics, where the sales of good $\mathrm{X}$ responds to a $1 \%$ change in price; that is, $\mathrm{E}_{\mathrm{x}}=\Delta \mathrm{Q}_{\mathrm{x}} / \Delta \mathrm{P}_{\mathrm{x}} \cdot \mathrm{P}_{\mathrm{x}} / \mathrm{Q}_{\mathrm{x}} \quad$ (E is the price elasticity, $\mathrm{P}$ represents product price and $\mathrm{Q}$ is the quantity of product sale). A number of WOM studies have demonstrated that the sales of goods respond to changes in WOM (Bansal \& Voyer, 2000; Goges \& Mayzlin, 2004). Thus, WOM elasticity follows the same logic to quantify the relation between WOM and the sales of goods, that is, the extent of WOM effects.

For the purpose of examining the usage of WOM elasticity, the authors found the power of word-of-mouth (recommendation by friends and family) is the most credible for leisure travelers (Murphy et al., 2007; Alvarez \& Asugman, 2006). For tourists, this recommendation of a product/service from a friend or family member is the most powerful information source available. It is also the least expensive. In the same time, lot of literatures emphasis the influence of travel blogs as a communications tool to travel information (as an electronic word-ofmouth) about travel experience (Pan et al., 2007; Schmallegger $\&$ Carson, 2008). And the continuing rise of the internet as a WOM communications tool for travel and tourism presents challenges for tourism enterprises. After leisure travelers obtain travel information either online or offline, many still need the validation of a travel professional, especially for more complex travel. It is essential for travel marketers to realize the sale is not consummated at time of booking or final deposit. Rather, it is after the customer consumes the travel experience of others. So, how to understand the real effect of the travel experience WOM? Thus, the authors choose 8 product categories of tour- 
ism industry to calculate the WOM elasticity values and compare the WOM effects on these product categories, and hope the results can generalized to other industries.

This study is organized as follows. The authors first devise a WOM sales function to integrate two major variables: tourism product sales and its WOM. Second, the authors use questionnaires to collect product purchasing information from experienced consumers. Third, the authors investigate two types (physical vs service) of products mentioned in the literature. Finally, the authors calculate the WOM elasticity value of the 8 product categories. Finally, the authors present the results and discuss the limitations and implications of how WOM and its effects impact each product category.

\section{Measuring Word-of-Mouth Influences}

\section{Elasticity Theory for Quantification and Comparison}

To understand the concept of WOM elasticity as applied to WOM marketing research; it is useful to briefly review previous marketing research within the elasticity framework. For example, Assmus et al. (1984) examined the elasticity framework and noted the absolute value of price elasticity is eight times that of advertising elasticity. Olivera-Castro (2008) applied price elasticity theory to brand selection; and Trusov et al. (2009) used the elasticity indicator to estimate that WOM is 20 times as effective as marketing events and 30 times as effective as media appearances. In general, these studies followed the elasticity theory to describe variables and compare their effecttiveness, and used the concept to integrate research themes and the variables of demand, sale, market share, and so forth, to discuss marketing effects. Moreover, some researchers add a time variable to understand elasticity trends in determining marketing strategies. Overall, academics support elasticity as a very useful concept that can be applied to the study of WOM.

\section{WOM Elasticity Logic}

WOM behavior means the number of people told about a product experience (Halstead \& Droge, 1991). Many WOM studies have found that a considerable proportion of consumers seek product WOM from the Internet or friends before buying goods (Bloch et al., 1986; Katona \& Mueller, 1954). Many of these studies have determined that positive WOM can increase the probability of product purchase (Ardnt, 1967; Katz \& Lazarfeld, 1955), and negative WOM can negatively influence purchasing decisions (Homburg et al., 2005; Mittal et al., 1998). That's means the product sales as a function of WOM as following:

$$
\text { Sales }_{x}=Q_{x}=f\left(\text { WOM }_{x}, \overline{\text { other factor }_{x}}\right)=f\left(\operatorname{WOM}_{x}\right)
$$

where $Q_{x}$ is the sales of product $\mathrm{X}, \mathrm{WOM}_{\mathrm{x}}$ is the WOM of product $\mathrm{X}$, and other factor $\mathrm{r}_{\mathrm{X}}$ is other variables (assumed to be fixed here) that can affect the product sales,

According to the WOM sales function above, the definition of the WOM elasticity of product $\mathrm{X}$ is as follow:

$$
\mathrm{E}_{\mathrm{WOM}_{\mathrm{x}}}=\frac{\Delta \mathrm{Q}_{\mathrm{x}} / \mathrm{Q}_{\mathrm{x}}}{\Delta \mathrm{WOM}_{\mathrm{x}} / \mathrm{WOM}_{\mathrm{x}}}=\frac{\Delta \mathrm{Q}_{\mathrm{x}}}{\Delta \mathrm{WOM}_{\mathrm{x}}} \times \frac{\mathrm{WOM}_{\mathrm{x}}}{\mathrm{Q}_{\mathrm{x}}}
$$

where $Q_{x}$ is the sales of product $X, \mathrm{WOM}_{x}$ is the WOM of product $\mathrm{X}, \Delta \mathrm{Q}_{\mathrm{x}} / \Delta \mathrm{WOM}_{\mathrm{x}}$ shows how $\mathrm{Q}_{\mathrm{X}}$ changes as $\mathrm{WOM}_{\mathrm{x}}$ changes, and this expression for $\mathrm{E}_{\mathrm{WOM}_{\mathrm{x}}}$ shows how the sales of $\mathrm{X}$ responds to a $1 \%$ change in $\mathrm{X}$ 's WOM.

\section{Research Hypotheses}

As above, WOM elasticity value ( $\left.\mathrm{E}_{\mathrm{WOM}}\right)$ can directly measure and compare WOM effects, shows that the differences in WOM effects are then related to differences in WOM elasticity. Accordingly, $\mathrm{E}_{\mathrm{wOM}}$ becomes an intermediate indicator integrating all influenced factors except WOM to WOM sale function so that can help us better understand WOM effects (see Figure 1). Thus, the first hypothesis in this study is concerned with the WOM elasticity value in tourism industry, this expected a positive value will be observed for all categories we will investigate. And second hypothesis is subjected to empirical examination of difference of WOM elasticity value between the service and physical products; in here the authors expected a larger value for service than physical products in this paper.

\section{Methodology}

\section{To Get the WOM Elasticity Values}

The economic theory logic is used to calculate the WOM elasticity value; thus, we must assume the other conditions are unchanged and the system is a closed economy (without foreign purchases). Therefore, the consumption equal product sale, the relation between a product's variables of consumption (C) and WOM is Equation (1).

\section{Mathematical Notations}

$$
\begin{aligned}
& \mathrm{Q}=\mathrm{C}=\mathrm{f}(\mathrm{WOM}) \\
& \mathrm{E}_{\mathrm{wOM}}=\frac{\Delta \mathrm{Q} / \mathrm{Q}}{\Delta \mathrm{WOM} / \mathrm{WOM}}=\frac{\Delta \mathrm{C} / \mathrm{C}}{\Delta \mathrm{WOM} / \mathrm{WOM}} \\
& \mathrm{C}=\mathrm{A}(\mathrm{WOM})^{\beta} \mathrm{e}^{\varepsilon} \\
& \ln C=\ln \mathrm{A}+\beta \ln (\mathrm{WOM})+\varepsilon \\
& \beta=\frac{\mathrm{d} \operatorname{lnC}}{\mathrm{d} \ln \mathrm{WOM}}=\mathrm{E}_{\mathrm{wOM}}{ }^{1} \\
& {\left[\begin{array}{c}
\ln C_{i 1} \\
\operatorname{lnC}_{\mathrm{i} 2} \\
\mathrm{M} \\
\ln C_{\mathrm{ip}} \\
\mathrm{M} \\
\operatorname{lnC} \mathrm{in}_{\mathrm{in}}
\end{array}\right]=\alpha+\beta_{\mathrm{i}}\left[\begin{array}{c}
\ln \mathrm{WOM}_{\mathrm{i} 1} \\
\ln _{\mathrm{WOM}} \\
\mathrm{M} \\
\ln \mathrm{WOM}_{\mathrm{ip}} \\
\mathrm{M} \\
\ln \mathrm{WOM}_{\mathrm{in}}
\end{array}\right]+\left[\begin{array}{c}
\varepsilon_{\mathrm{i} 1} \\
\varepsilon_{\mathrm{i} 2} \\
\mathrm{M} \\
\varepsilon_{\mathrm{ip}} \\
\mathrm{M} \\
\varepsilon_{\mathrm{in}}
\end{array}\right]}
\end{aligned}
$$

where Q is the product sales; $\mathrm{C}$ is the consumption of goods, an independent variable in this study's framework; and WOM is the product WOM, a dependent variable. Given Equation (1),

${ }^{1}$ Setting $\ln \mathrm{A}=\alpha$, a constant, we differentiate Equation (4) by WOM as follows:

$$
\begin{gathered}
\frac{\mathrm{dlnC}}{\mathrm{dWOM}}=\frac{\mathrm{d} \alpha}{\mathrm{dWOM}}+\beta \times \frac{\mathrm{dlnWOM}}{\mathrm{dWOM}}+\frac{\mathrm{d} \varepsilon}{\mathrm{dWOM}} \\
\mathrm{P} \frac{1}{\mathrm{C}} \times \frac{\mathrm{dC}}{\mathrm{dWOM}}=0+\beta \times \frac{1}{\mathrm{WOM}}+0 \\
\text { where } \beta=\frac{1 / \mathrm{C} \cdot \mathrm{dC} / \mathrm{dWOM}}{1 / \mathrm{WOM}}=\frac{\mathrm{dC} / \mathrm{C}}{\mathrm{dWOM} / \mathrm{WOM}}=\mathrm{E}_{\mathrm{wOM}}
\end{gathered}
$$




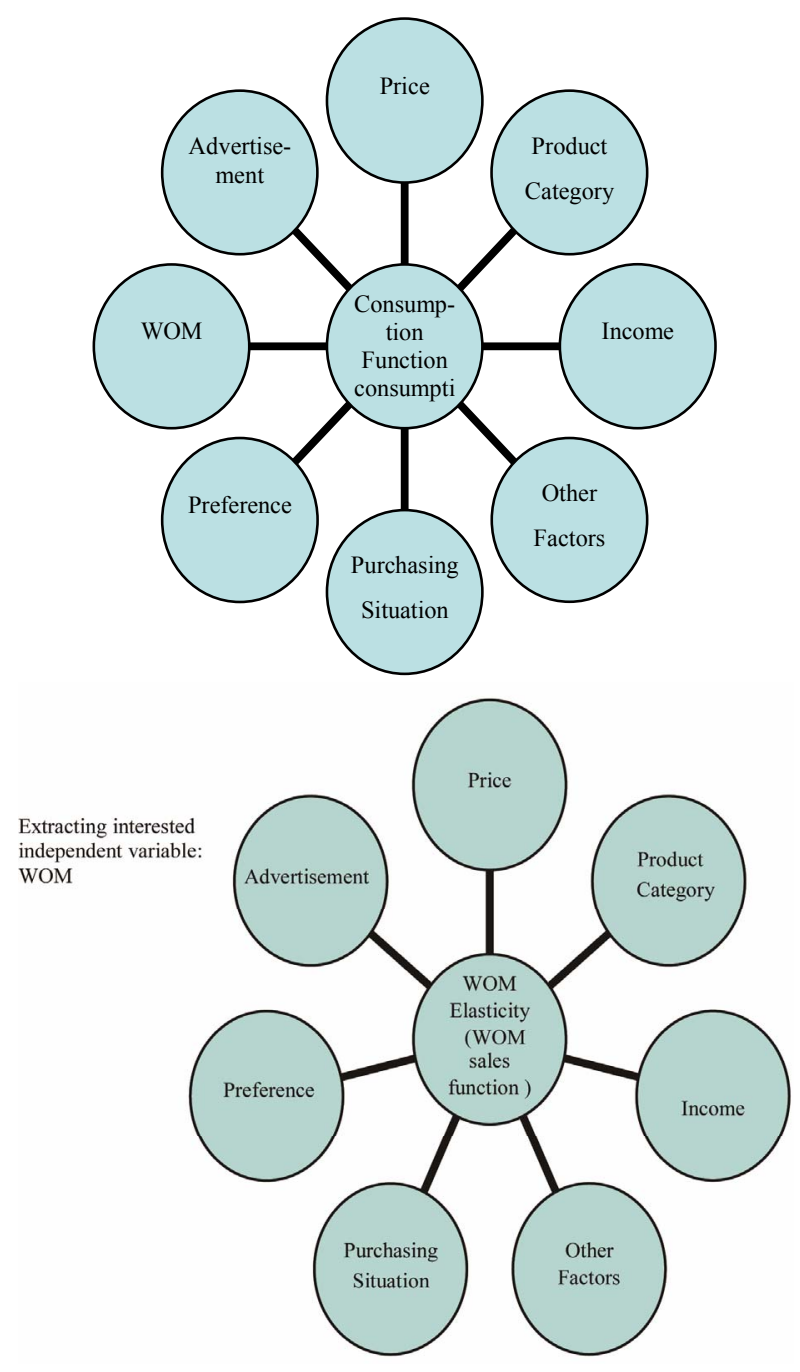

Figure 1.

Mechanism of WOM influence. Original state: Consumption function is influenced by many factors; Present state: Assuming other independent variables are fixed. *The outer circle are independent variables, the centre circle is dependent variable.

the definition of WOM elasticity ( $\mathrm{E}_{\mathrm{WOM}}$ ) is Equation (2), where $\Delta \mathrm{Q}$ is the change in the amount of sales, $\Delta \mathrm{C}$ is the change in the consumption, and $\triangle \mathrm{WOM}$ is the change in WOM.

Finally, as in Equation (3), a basic function type is set as a Cobb-Douglas functional form, which is very easy to manipulate and has been widely used in prior studies in various fields (e.g., Costrell \& Loury, 2004; Wirjanto, 2004); In Equation (3), where $\mathrm{e}$ is an exponential, $\mathrm{A}$ and $\beta$ are constants, and $\varepsilon$ is a random variable. We then take the natural logarithm (ln) to plus on both sides of Equation (3) to obtain a simple linear regression equation as Equation (4).

In Equation (5), $\beta$ is the value of continuous WOM elasticity $\left(E_{\text {wом }}\right)$. When the samples are from the same distribution, the logarithm of consumption of product categories and WOM has a linear relation, as in Equation (6), an econometric model specification.

In Equation (6), where $\mathrm{E}\left(\varepsilon_{\text {ip }} / \mathrm{WOM}_{\text {ip }}\right)=0$; $\operatorname{Var}\left(\varepsilon_{\mathrm{ip}} / \mathrm{WOM}_{\mathrm{ip}}\right)=\sigma^{2}$ (homoskedasticity), $\alpha$ and $\beta$ are the estimated regression coefficients, $\varepsilon$ represents the error term, $\mathrm{n}$ is the number of effective samples, $\mathrm{WOM}_{\mathrm{ip}}$ is the WOM evaluation of consumer $\mathrm{p}$ of product $\mathrm{i}$ (equal to the degree consumer $p$ is influenced by the WOM of product $i$ ), $\mathrm{C}_{\mathrm{ip}}$ is the amount of product $\mathrm{i}$ consumed by consumer $\mathrm{p}$, and $\beta_{\mathrm{i}}$ is the $\mathrm{E}_{\mathrm{wOM}}$ in product i's category.

\section{Samples and Data Collections}

For the tourism this research concerned, the authors screen 8 different categories of physical product and service to enhance our understanding of WOM effects among different products, including transportation, accommodation, meals, guiding, souvenir, admission, travel agency, scenic spots as objectives for this investigation. We subsequently designed an appropriate questionnaire and deliver to 300 customers in tourism site (hotel and restaurant) for two week, and then we successfully collect travel experiences of 241 tourists who consumed all or some of these product categories. The questionnaire example for all product categories is as following: (a group of three questions for one product; $\mathrm{X}$ is transportation or accommodation or meals or...).

- A) When you go traveling, have you ever bought product X over because of its word of mouth? $\rightarrow$ If your answer is yes, then continue to answer the next two questions.

- B) By what degree were you influenced by word of mouth of product X? (Please evaluate your feeling about X's WOM, in the range $1-100$ ).

- C) How much did you spend purchasing product X? (new Taiwan dollars).

Since the objective measurement of WOM is complex, the alternative of the extent to which WOM recipients were influenced by WOM (Bansal \& Voyer, 2000) is the standard of WOM measurement (degree 1 - 100) in this questionnaire. After two weeks data collected by random sampling, there are 241 effective samples for calculating the WOM elasticity values of the 8 products in tourism.

For each product, a group of three questions was designed. Because this questionnaire is measured differently from the traditional scale, the past instrument is not suitable for testing the validity of this questionnaire. When we focus on the single independent factor WOM that is simply understand the goal of this questionnaire. Every product must be regarded as a different aspect from others in this study, and the three questions can construct to an independent questionnaire that is not necessary to test the validity. Maybe in the future, when an extended questionnaire is developed and the expert validity could verify to detect the new developing scale.

The authors sample randomly to raise the reliability, and screened 19 effective responders to test-retest to observe the correlation coefficient to observe the reliability for this questionnaire (the period of test-retest is interval of two weeks). The results of test-retest method are in Table 1, fortunately, the authors found the correlation coefficients are large enough to rely on; thus we can rule out the matter of no response set and external validation and expect to increase samples is not apparent to rise contribution.

In this study, the theoretical parameter values of both research variables (WOM and C) are unknown. In addition, the findings of previous literature conclude in lack of consensus in tourism product. Thus it is hard to test the representativeness of samples by statistic method, but we collect data in tourism site 
Table 1.

The test-retest reliability results.

\begin{tabular}{ccc}
\hline & Product category & Correlation coefficient \\
\hline $\begin{array}{c}\text { Total point of WOM } \\
\text { evaluation and } \\
\text { consumption }\end{array}$ & Transportation & 0.93 \\
& Accommodation & 0.85 \\
& Meals & 0.87 \\
& Guiding & 0.84 \\
Total point of WOM & Travel agency & 0.89 \\
evaluation and & Admission & 0.87 \\
& Souvenir & 0.96 \\
Total & Scenic spots & 0.90 \\
\hline
\end{tabular}

(hotel and restaurant) for suitable sample is acceptable and, the WOM evaluation is a subjective variable and consumption is depended on consumer's purchasing pattern is already understanding, too.

\section{Results}

Following the mathematical notations in page 3 , the authors obtain results by simple linear regression method. Table 2 presents the results of data analysis for a closed economy, where $\beta$ is a direct measure of the WOM elasticity of the 8 product categories. The results clearly show that the $\beta$ value of all categories of goods is greater than zero, and in which findings of all product categories are significant except scenic spots, then results in WOM with a positive enhancement can promote product consumption.

The WOM elasticity results for the product categories are different, proving that WOM effects vary across products. Therefore, WOM elasticity is a considerable source of influence that leads to different WOM effects. Furthermore, the empirical analysis examined that $1 \%$ changes in WOM have a positive percentage impact on the sales of goods, except scenic spots.

Our results indicate that these goods are services have WOM elasticity values ranging from 0.58 to 1.29 . Murray (1991) found that consumers use personal sources of information more when looking for service providers than when looking for physical goods, and the more expert the product knowledge, the greater the WOM influence on consumer decision making (Bansal \& Voyer, 2000; Gilly et al., 1998; Rabaglietti et al, 2011), and the more lasting the effects (Berry, 1995). For most of the product of tourism, experience goods (Smith \& Swinyard, 1982) also have a large influence like the travel agency, guiding or accommodation.

However, these goods are physical have lower WOM elasticity values ranging from 0.21 to 0.64 , even that the result of scenic spots is not significant, for three possible reasons. First, as the post research speaking that physical good with less WOM influence; second, the consumption of these products is not necessary in traveling; and third, the tourists' evaluation of scenic spots have great response difference.

The results means WOM wields considerable influence on
Table 2.

Results of the data analysis of the 8 product categories.

\begin{tabular}{cccccc}
\hline Attribute & $\begin{array}{c}\text { Product } \\
\text { category }\end{array}$ & $\alpha$ & $\beta$ (EWOM) & $p$ value & $\begin{array}{c}\text { Significant } \\
(\rho<0.1)\end{array}$ \\
\hline \multirow{6}{*}{ Service } & Transportation & 3.83 & 0.58 & 0.03 & $* *$ \\
& Accommodation & 4.24 & 0.78 & 0.06 & $*$ \\
& Meals & 2.53 & 0.75 & 0.05 & $* *$ \\
& Guiding & 3.03 & 1.03 & 0.02 & $* *$ \\
& Travel agency & 5.53 & 1.29 & 0.09 & $*$ \\
\multirow{2}{*}{ Physical } & Admission & 4.40 & 0.21 & 0.03 & $* *$ \\
& Souvenir & 6.82 & 0.33 & 0.10 & $*$ \\
\multirow{2}{*}{$\begin{array}{c}\text { Average } \\
\text { of total }\end{array}$} & Scenic spots & 7.57 & 0.64 & 0.23 & \\
\hline
\end{tabular}

The sign of two stars $\left(^{* *}\right)$ is $\rho<0.05$ that represent the result is very significant, and one stars $\left({ }^{*}\right)$ is $0.05 \leqq \rho<0.1$ that represent the result is significant.

consumer purchases in tourism product categories, and the average evaluation of WOM for all product categories is 77.89 (highest score is 100, see Table 3), which reveals that the consumer would purchase goods if he or she had a stronger feeling about the WOM and ensures that WOM is an effective marketing tool in tourism. The power of WOM observed in this study's results echoes previous researchers who emphasized that WOM can make the difference between product success and failure (e.g., Godes \& Mayzlin, 2004; Laczniak et al., 2001).

\section{Discussion}

\section{Theoretical Implications}

The most important theoretical implication in this study is the concept of WOM elasticity was designed to an intermediate indicator to integrate all factors which may affect the product sales, then used to calculate and compare the WOM influence on product sales. Although prior research has greatly taken the use of elasticity theory to increase our understanding of social science, most studies have focused solely on single event (product) appearance or on a variety of products.

Remarkably, we have no one-size-fits-all standard to quantify WOM to estimate WOM elasticity value; however, we can bypass WOM measurement by using each recipient's personal, subjective assessment of WOM influence. Note that the WOM recipients (consumers) are the purchase decision makers (Sweeney, 2008) evaluating how WOM affects their decision making and expectations of consumptions (Devlin et al., 2002; Webster, 1991).

This scale of WOM elasticity limits the ability of academics to copy with the complex of WOM variable (e.g. negative WOM), and hope to develop improved technology (construct the panel data base for long term) for future use. One implication from the findings is that although consumers can be put into segmented classes according to their purchase expenditures it may not translate into purchase quantity. However, the introduction of the concept of economic elasticity as an implement to provide a simple method to quantify and compare WOM effects that found WOM elasticity values showed a statistical difference and that it has a significant WOM influence on ser- 
Table 3.

Results of the data analysis of the 8 product categories (continued).

\begin{tabular}{cccccc}
\hline \multirow{2}{*}{ Attribute } & $\begin{array}{c}\text { Product } \\
\text { category }\end{array}$ & $\begin{array}{c}\text { Mean of WOM Evaluation } \\
(0<\mu<100)\end{array}$ & $\begin{array}{c}\text { standard deviation of WOM } \\
\text { Evaluation }(\sigma)\end{array}$ & effective sample (n) & Ratio of effective sample (n/241) \\
\hline \multirow{5}{*}{ Service } & Transportation & 80.48 & 18.81 & 207 & $86 \%$ \\
& Accommodation & 74.56 & 13.78 & 223 & $93 \%$ \\
& Meals & 77.12 & 19.73 & 181 & $75 \%$ \\
& Guiding & 90.07 & 15.64 & 122 & $51 \%$ \\
& Travel agency & 84.72 & 14.83 & 109 & $72 \%$ \\
& Admission & 66.53 & 22.29 & 138 & $57 \%$ \\
Physical & Souvenir & 71.29 & 16.25 & 215 & $57 \%$ \\
& Scenic spots & 78.34 & 17.13 & 171 & $89 \%$ \\
\hline
\end{tabular}

vice purchase than physical product purchase in tourism; thus, we can incorporate them into a variety of product categories of tourism of marketing strategies.

\section{Managerial Implications}

The present study illustrates the differences in WOM elasticity impact on WOM influences. The purpose of this study is to explore the WOM origins so that we can quantify the relation between product sales and WOM, which offers an approach for tourism managers to compare WOM effects with those of other marketing tools. After product WOM spread, firms of tourism relative should collect consumers' WOM evaluations over time to estimate the WOM variation to calculate the immediate, short-term, and long-term WOM elasticity values of products of tourism. Managers can consider product WOM elasticity to develop marketing strategies and increase the effectiveness of marketing resource allocation.

The results show that, a proportion (see Figure 2) of the respondents are highly influenced by product WOM, which means that consumers will consume the tourism product if they feel good about its WOM. However, managers cannot objecttively measure consumers' feelings of WOM if a standard measurement of consumer perception does not exist. This study introduces the subjective measurement of WOM as a measurement of utility and makes it easy to screen out the target consumer group of tourism WOM marketing. Thus, firms should include in their after-purchase surveys a questionnaire item for WOM, under "the evaluation of WOM when you have consumed," in addition to the question on reason for purchase. Efforts to study the WOM evaluation of consumers who are easily influenced by WOM will effectively increase product revenue. Furthermore, we even suggest applying WOM elasticity in customer relations management to gauge WOM effects on individual customers to analyze their buying patterns.

\section{Conclusion}

The concept of WOM elasticity can be established to quantify WOM influences, and the value of WOM elasticity can be calculated by a subjective measure of WOM, the literature on WOM elasticity definitions (Trusov et al., 2009) have been receiving increased attention. This study increases our understanding of this potential issue for future research. The main conclusions of this study are as follows.

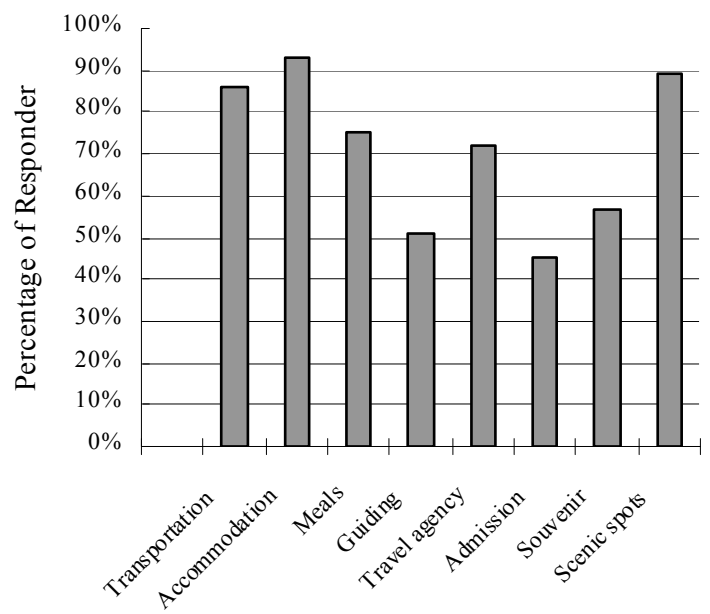

Product Category

Figure 2.

Ratio of consumption responding to WOM.

First, we integrated the influenced factor on WOM to quantify the relation between product sales and WOM. Second, we examine the responses of 241 tourists for 8 product categories were proved with different WOM influences on product sales due to the different WOM elasticity of product. And the WOM elasticity of services is much greater than physical products. Third, we substitute the WOM recipients' evaluations for WOM communicators' spread quantities (Brown et al., 2005; Harrison-Walker, 2001) to measure WOM, turning an objective variable into a subjective one, firms should find calculations of WOM elasticity of product categories to be helpful in managing the marketing resources for their products, then to establishing a trend of WOM elasticity would be a powerful tool in the management of WOM marketing on the products like travel agency, guiding and accommodation.

\section{Further Research}

This study the concept of WOM elasticity had applied to the tourism industry, otherwise, we must use indicator of WOM elasticity to estimate the WOM effects on products of other industries for generalization. In practice, we provide a simple and useful method for measuring WOM variations without any 
quantitative units (number or length of time). WOM can be subjectively measured on the premise that consumers understand their own perceptions and preferences, so firms can estimate product WOM elasticity directly by asking consumers feelings about WOM. Moreover, it will be helpful to add a time variable to analyze WOM effects in the short and long run for further research.

Another issue is that WOM affects not only product categories but other factors, such as consumer loyalty and communication sites. In addition, the indicator of WOM elasticity can be used to compare the effectiveness of WOM marketing activities with other marketing tools (such as price promotion or advertising), this is also a worthwhile issue for future study.

Finally, the concept of WOM elasticity can be extended to quantify WOM influences among brands. Taylor (1997) found that cross-brand WOM also affects consumer attitudes and behavior (Libai et al., 2009). Therefore, we can apply crossprice elasticity theory to constructing the concept of "crossWOM elasticity" for WOM among the different brands.

The present study illustrates the differences in WOM elasticity impact on WOM influences. The purpose of this study is to explore the WOM origins so that we can quantify the relation between product sales and WOM, which offers an approach for tourism managers to compare WOM effects with those of other marketing tools.

\section{Acknowledgements}

We would like to thank the anonymous referees for their valuable comments and suggestions. The authors can be contacted at fion@ccms.nkfust.edu.tw or D9308201@mail.ntust.edu.tw.

\section{REFERENCES}

Alvarez, M., \& Asugman, G. (2006) Explorers versus planners: A study of Turkish tourists. Annals of Tourism Research, 33, 319-338. doi:10.1016/j.annals.2005.12.001

Arndt, J. (1967). Role of product-related conversations in the diffusion of a new product. Journal of marketing Research, 4, 291-229. doi:10.2307/3149462

Assmus, G., Farley, J. U., \& Lehmann, D. R. (1984). How advertising affects sales: Meta-analysis of econometric results. Journal of Marketing Research, 21, 65-74. doi:10.2307/3151793

Bansal, H. S., \& Voyer, P. A. (2000). Word-of-mouth processes within a services purchase decision context. Journal of Service Research, 3, 166-177. doi:10.1177/109467050032005

Bayus, B. L. (1985). Word of mouth: The indirect effects of marketing efforts. Journal of Advertising Research, 25, 31-39.

Berry, L. L. (1995). Relationship marketing of services-Growing interest, emerging perspectives. Journal of the Academy of Marketing Science, 23, 236-245. doi:10.1177/009207039502300402

Bloch, P. H., Sherrell, D. L., \& Ridgway, N. M. (1986). Consumer search: An extended framework. Journal of Consumer Research, 13, 119-126. doi:10.1086/209052

Brown, T. J., Barry, T. E., Dacin, P. A., \& Gunst, R. F. (2005). Spreading the word: Investigating antecedents of consumers' positive wordof-mouth intentions and behaviors in a retailing context. Journal of the Academy of Marketing Science, 33, 123-138. doi: $10.1177 / 0092070304268417$

Christiansen, T., \& Tax, S. S. (2000). Measuring word of mouth: The questions of who and when? Journal of Marketing Communications, 6, 185-199. doi:10.1080/13527260050118676

Costrell, R. M., \& Loury, G. C. (2004). Distribution of ability and earnings in a hierarchical job assignment model. Journal of Political Economy, 112, 1322-1363. doi:10.1086/424741
Crane, F. G., \& Lynch, J. E. (1988). Consumer selection of physicians and dentists: An examination of choice criteria and cue usage. Journal of Health Care Marketing, 8, 16-19.

Derbaix, C. (1983). Perceived risk and risk relievers: An empirical investigation. Journal of Economic Psychology, 3, 19-38. doi:10.1016/0167-4870(83)90056-9

Devlin, J. F., Gwynne, A. L., \& Ennew, C. T. (2002). The antecedents of service expectations. The Service Industries Journal, 22, 117-152. doi:10.1080/714005102

Dodson, J. A., \& Muller, E. (1978). Models of new product diffusion through advertising and word-of-mouth. Management Science, 24, 1568-1578. doi: $10.1287 / \mathrm{mnsc} .24 .15 .1568$

Ennew, C., Bauerjee, A. K., \& Li, D. (2000). Managing word of mouth communication: Empirical evidence from India. International Journal of Bank Marketing, 18, 75-83. doi:10.1108/02652320010322985

Fang, C. H., Lin, T. M. Y., Liu, F., \& Lin, Y. H. (2011). Product type and word of mouth: A dyadic perspective, Journal of Research in Interactive Marketing, 5, 189-202. doi:10.1108/17505931111187802

File, K. M., Cermak, D. S. P., \& Prince, R. A. (1994). Word-of-mouth effects in professional service buyer behaviour. The Service Industries Journal, 14, 301-314. doi:10.1080/02642069400000035

Forsythe, S. M. (2003). Consumer patronage and risk perceptions in internet shopping. Journal of Business Research, 56, 867-875. doi:10.1016/S0148-2963(01)00273-9

Godes, D., \& Mayzlin, D. (2004). Using online conversations to study word-of-mouth communication. Marketing Science, 23, 545-560. doi: $10.1287 / \mathrm{mksc} .1040 .0071$

Halstead, D., \& Droge, C. (1991) Consumer attitudes toward complaining and the prediction of multiple complaint responses. Advances in Consumer Research, 18, 210-216.

Harrison-Walker, L. J. (2001). The measurement of word-of-mouth communication and an investigation of service quality and customer commitment as potential antecedents. Journal of Service Research, 4, 60-75. doi: $10.1177 / 109467050141006$

Homburg, C., \& Furst, A. (2005). How organizational complaint handling drives customer loyalty: An analysis of the mechanistic and the organic approach. Journal of Marketing, 69, 95-114. doi:10.1509/jmkg.69.3.95.66367

Kiel, G. C., \& Layton, R. A. (1981). Dimensions of consumer information seeking behavior. Journal of marketing Research, 18, 233-239. doi: $10.2307 / 3150957$

Laczniak, R. N., Decarlo, T. E., \& Ramaswami, S. N. (2001). Consumers' responses to negative word-of-mouth communication: An attribution theory perspective. Journal of Consumer Psychology, 11, 57 73. doi:10.1207/S15327663JCP1101 5

Lam, D., \& Mizerski, D. (2005). The effects of locus of control on word-of-mouth communication. Journal of Marketing Communication, 11, 215-228. doi:10.1080/1352726042000333180

Lan, M. Y., Liu, F. Y., Fang, C. H., \& Lin, T. M. Y. (2012) Understanding word-of-mouth in counterfeiting, Psychology, 3, 289-295. doi: $10.4236 /$ psych.2012.33041

Libai, B., Muller, E., \& Peres, R. (2009). The role of within-brand and cross-brand communications in competitive growth. Journal of Marketing, 73, 19-34. doi:10.1509/jmkg.73.3.19

Mahajan, V., Muller, E., \& Bass, F. M. (1990). New product diffusion models in marketing: A review and directions for research. Journal of Marketing, 54, 1-26. doi:10.2307/1252170

Mittal, V., Ross, W., \& Baldasare, P. (1998). The asymmetric impact of negative and positive attribute-level performance on overall satisfaction and repurchase intentions. Journal of Marketing, 62, 33-47. doi: $10.2307 / 1251801$

Murphy, L., Mascardo, G., \& Benckendorff, P. (2007). Exploring word-of-mouth influences on travel decisions: Friends and relatives vs other travelers. International Journal of Consumer Studies, 31, 517-527. doi:10.1111/j.1470-6431.2007.00608.x

Murray, K. B. (1991). A test of services marketing theory: Consumer information acquisition activities. Journal of Marketing, 55, 10-25. doi: $10.2307 / 1252200$

Oliveira-Castro, J. M., Foxall, G. R., \& Schrezenmaier, T. C. (2005). Patterns of consumer response to retail price differentials. The Service Industries Journal, 25, 309-335. 
doi:10.1080/02642060500050392

Pan, B., MacLaurin, T., \& Crotts, J. C. (2007). Travel blogs and the implications for destination. Marketing Journal of Travel Research, 46, 35-45. doi: $10.1177 / 0047287507302378$

Rabaglietti, E., Liubicich, M. E., \& Ciairano, S. (2011). Gender differ-ences in the relationships between physical activity and the psycho-logical and physical self-reported condition of the elderly in a resi-dential care facility. Psychology, 2, 35-41.

doi:10.4236/psych.2011.21006

Schmallegger, D., \& Carson, D. (2008). Blogs in tourism: Changing approaches to information exchange. Journal of Vacation Marketing, 14, 99-110. doi: $10.1177 / 1356766707087519$

Smith, R. E., \& Swinyard, W. R. (1982). Information response models: An integrated approach. Journal of Marketing, 46, 81-93.

doi: $10.2307 / 1251162$

Sweeney, J. C., Soutar, G. N., \& Mazzarol, T. (2008). Factors influencing word of mouth effectiveness: Receiver perspectives. European Journal of Marketing, 42, 344-364. doi: $10.1108 / 03090560810852977$

Sui, J. J., \& Baloglu, S. (2003). The role of emotional commitment in relationship marketing: An empirical investigation of a loyalty model for casinos. Journal of Hospitality \& Tourism Research, 27, 470-489.

Taylor, K. A. (1997). A regret theory approach to assessing consumer satisfaction. Marketing Letters, 8, 229-238. doi:10.1023/A:1007966621364

Trusov, M., Bucklin, R. E., \& Pauwels, K. (2009). Effects of word-ofmouth versus traditional marketing: Findings from an Internet social networking site. Journal of Marketing, 73, 90-102. doi:10.1509/jmkg.73.5.90

Villanueva, J., Yoo, S., \& Hanssens, D. M. (2008). The impact of marketing-induced vs word-of-mouth customer acquisition on customer equity. Journal of marketing Research, 45, 48-59.

doi: $10.1509 / \mathrm{jmkr} .45 .1 .48$

Webster, C. (1991). Influences upon consumer expectations of services. The Journal of Services Marketing, 5, 5-17. doi:10.1108/08876049110035440

Wirjanto, T. S. (2004). Exploring consumption-based asset pricing model with stochastic-trend forcing processes. Applied Economics, 36, 1591-1597. doi:10.1080/0003684042000217940 